ISSN : $2620-4665$ (print)

ISSN : 2620 - 4673 (online)

Website : http://jurnal.untan.ac.id/index.php/JPLP2KM

\title{
INTRODUKSI PENCEGAHAN KEBAKARAN LAHAN PERTANIAN DI AREA GAMBUT PADA ANAK USIA SEKOLAH DASAR
}

\author{
Anita Suharyani ${ }^{*}$, Maswadi2, Shenny Oktoriana ${ }^{3}$ \\ Jurusan Sosial Ekonomi Pertanian, Universitas Tanjungpura, Pontianak \\ *Email: anita.suharyani@faperta.untan.ac.id
}

\begin{abstract}
ABSTRACK
Burning behavior in the peatland area in Bengkayang District is still running which is caused many disadvantages. To solve it, we need to prevention and handling activities. prevention activity is better to do which is the target all the society include children. children have imitation characteristic, include burning behavior. therefore, the introduction of land burning prevention necessary to do with fun method and media. This activity was conducted in SDN 4 Sungai Jaga A Sungai Raya Sub-district Bengkayang district as much as 31 students in fourth grade. The methodology that was used with lecturer and tale and used the poster, puppets, and banner as media. Participants very excited when activities occur. hopefully, children have the knowledge, commit good behavior and concern to their environment.
\end{abstract}

Keywords: Prevention, Land Burning, Agriculture, Peatland

\section{PENDAHULUAN}

Kalimantan Barat merupakan salah satu provinsi yang memiliki jumlah lahan gambut yang cukup luas di Indonesia dimana salah satu bentuk pemanfaatannya adalah sebagai lahan pertanian. Kebaran lahan dan hutan pada area gambut menjadi masalah yang berulang kali terjai. Bahkan, pada tahun 2015 kebakaran lahan dan hutan menyebabkan Indonesia berhasil "mengekspor asap" di beberapa negara tetangga seperti Malaysia dan Singapura. Menurut Badan Penelitian dan Pengembangan Pertanian Kementerian Pertanian (2014), sebagian besar $(90 \%)$ kebakaran lahan disebabkan oleh faktor manusia, terutama dalam kegiatan pembukaan lahan (land clearing).

Kabupaten Bengkayang merupakan daerah yang sering mengalami kebakaran kebakaran lahan dan hutan pada area gambut. Perilaku membakar lahan biasanya dilakukan oleh masyarakat yang sebagian besar bermata pencaharian sebagai petani dikarenakan beberapa faktor seperti oleh kondisi sosial dan kondisi usahatani (Tim Survey SOSEK UNTAN, 2014). Kondisi sosial yang mempengaruhi yaitu konflik kepemilikan lahan, status kepemilikan lahan, konflik dengan pemilik lahan sekitar dan interaksi dengan pemilik lahan sekitar. Sedangkan 
kondisi usahatani yang mempengaruhi yaitu permasalahan usahatani, meteri penyuluhan pertanian, dan tingkat penerapan teknologi.

Dampak yang ditimbulkan dari kebakaran lahan pertanian di area gambut cukup menganngu aktivitas masyarakat. Oleh karena itu, pemerintah telah mengeluarkan undangundang tentang pembakaran lahan yang diantaranya diatur dalam Undang-undang Nomor 41 tahun 1999 tentang Kehutanan, Undang-undang Nomor 32 Tahun 2009 tentang Perlindungan dan Pengelolaan Lingkungan Hidup dan Undang-undang Nomor 39 Tahun 2014 tentang perkebunan. meskipun demikian, pemberlakuan undang-undang tersebut masih belum optimal apabila tidak dilakukan sosialisasi maupun pencegahan, karena pada hakikatnya mencegah lebih baik.

Sosialisasi dampak kebakaran lahan dan pencegahan kebakaran lahan pertanian di area gambut hendaknya dilakukan ke semua kalangan mulai dari anak-anak sampai dengan orang dewasa sehingga antar warga dapat bertindak sebagai pengawas. Salah satu sasaran dalam kegiatan pencegahan kebakaran lahan di area gambut adalah anak-anak. Hal ini dikarenakan mereka memiliki sifat untuk meniru kegiata yang dilakukan oleh orang-orang di sekitarnya tanpa mengetahui baik buruknya. Oleh karena itu, perlu dilakukan introduksi atau pengenalan tentang dampak negatif kebakaran lahan pertanian pada area gambut serta pencegahannya kepada anak-anak dengan cara bermain sambil belajar melalui dongeng.

Penyampaian materi melalui dongeng diharapkan mampu memberikan pemahaman secara lebih mudah kepada anak-anak usia sekolah dasar sehingga informasi yang disampaikan dapat diserap dengan baik dan tepat sasaran. Melalui kegiatatan introduksi pencegahan kebakaran lahan pertanian di area gambut pada anak usia sekolah dasar dapat mempengaruhi pandangan dan perilaku mereka mengenai kebakaran lahan pertanian sehingga nantinya bisa menjadi agen perubahan dan kebakaran lahan pertanian di area gambut dapat menurun. Adapun tujuan dari kegiatan introduksi pencegahan kebakaran lahan pertanian di area gambut pada anak sekolah dasar adalah untuk mengedukasi siswa usia sekolah dasar untuk peduli terhadap lingkungan terutama kebakaran lahan pertanian di area gambut, mengedukasi siswa usia sekolah dasar untuk peduli terhadap pencegahan kebaran lahan pertanian di area gambut, dan menyediakan media edukasi pencegahan kebaran lahan pertanian di area gambut untuk anakanak sekolah dasar. 
ISSN : $2620-4665$ (print)

ISSN : 2620 - 4673 (online)

Website : http://jurnal.untan.ac.id/index.php/JPLP2KM

\section{TINJAUAN PUSTAKA}

\subsection{KEBAKARAN LAHAN DAN HUTAN}

Menurut Badan Nasiobal Penanggulangan Bencana (2017), menyatakan bahwa kebakaran hutan dan lahan adalah suatu keadaan dimana hutan dan lahan dilanda api sehingga mengakibatkan kerusakan hutan dan lahan yang menimbulkan kerugian ekonomis dan atau nilai lingkungan, kebakaran hutan dan lahan seringkali menyebabkan bencana asap yang dapat menganggu aktivitas dan kesehatan masyarakat sekitar. Kebakaran lahan dan hutan disebabkan oleh beberapa hal, antara lain:

1. Aktivitas manusia yang menggunakan api di kawasan hutan dan lahan sehingga menyebabkan kebakaran.

2. Faktor alam yang dapat memicu terjadinya kebakaran hutan dan lahan.

3. Jenis tanaman yang sejenis dan memiliki titik bakar yang rendah serta hutan yang terdegradasi menyebabkan semakin rentan terhadap banyak kebakaran.

4. Angin yang cukup besar dapat memicu dan mempercepat menjalarnya api.

5. Topografi hutan yang terjal semakin mempercepat merembetnya api dari bawah ke atas.

Kebakaran hutan mengakibatkan kerugian berupa korban manusia dan hutan dan lahan milik negara. Hal ini dapat menganggu dan bahkan melumpuhkan kegiatan sosial dan ekonomi penduduk, antara lain:

1. Kerusakan ekologis yang mempengaruhi sistem penunjang kehidupan

2. Terganggunya kegiatan transportasi darat dan udara karena asap yang pekat mengakibatkan jalan raya tidak terlihat jelas. Sementara itu, bandar udara yang tertutup asap menyebabkan terganggunya aktivitas bandara seperti pesawat yang tidak bisa terbang atau mendarat dikarenakan terganggunya jarak pandang pilot.

3. Hilangnya potendi kekayaan hutan, fauna dan flauranya.

4. Penurunan kualitas kesehatan masyarakat untuk daerah yang luas di sekitar daerah kebakaran.

5. Turunnya pendapatan pemerintah dan masyarakat akibat terganggunya transportasi dan aktivitas ekonomi.

6. Musnahnya aset negara dan sarana prasarana vital. 


\subsection{Mitigasi Bencana}

Upaya mitigasi bencana kebakaran hutan dan lahan dibagi menjadi dua yaitu:

1. Mitigasi non struktural, yaitu bukan upaya pembangunan fisik dengan memanfaatkan pengetahuan, tindakan dan kesepakatan untuk mengurangi risiko dan dampak bencana. Secara khusus ini meliputi undang-undang dan kebijakan, peraturan, pedoman kegiatan peningkatan kesadaran publik, pelatihan dan pendidikan.

2. Mitigasi struktural, yaitu upaya pembangunan fisik untuk mebgurangi atau menghindari kemungkinan akibat atau dampak bahaya bencana atau serta penerapan teknologi serta arsitektur dan sistem bangunan yang kuat agar tahan hantaman bahaya bencana.

\section{Karakteristik Pengembangan Anak Usia Sekolah Dasar}

Anak-anak usia sekolah dasar memiliki karakteristik yang sangat unik dan berbeda-beda antar setiap individunya. Anak usia sekolah dasar lebih senang bermain, senang bergerak, senang bekerja kelompok dengan teman sebayanya, dan senang merasakan atau melakukan sesuatu secara langsung. Perkembangan siswa sekolah dasar usia 6-12 tahun yang termasuk pada perkembangan masa pertengahan (middle childhood) memiliki fase-fase yang unik dalam perkembangannya yang menggambarkan peristiwa penting bagi siswa yang bersangkutan. Teori perkembangan anak pada usia sekolah khususnya sekolah dasar dewasa ini kurang mendapatkan perhatian secara profesional dalam membentuk karakteristik dan perkembangan peserta didik sesuai dengan usia perkembangannya. Pengaruh perkembangan peserta didik lebih didominasi oleh pengaruh-pengaruh dari lingkungan luar (masyarakat).

Sejalan dengan itu, teori perkembangan Vygotsky menekankan pentingnya pola sosiokultural dimana individu menjadi salah satu unsurnya. Maksudnya, interaksi sosial memiliki peranan yang sangat mendasar dalam perkembangan kognitif anak. Selain genetik dan lingkungan, perkembangan dipengaruhi oleh campuran kekuatan sosial yang mengitari individu anak. Perubahan-perubahan kualitatif yang terus terjadi di lingkungan dan pada diri individu anak menghasilkan pencapaian perkembangan baru dan menandai titik tolak perkembangan baru.

Tahapan proses pembelajaran meliputi delapan fase yaitu, (1) motivasi; (2) pemahaman; (3) pemerolehan; (4) penyimpanan; (5) ingatan kembali; (6) generalisasi; (7) perlakuan dan (8) umpan balik. Teori pemrosesan informasi adalah teori kognitif tentang belajar yang menjelaskan pemrosesan, penyimpanan, dan pemanggilan kembali pengetahuan dari otak (Slavin, 2000: 
ISSN : $2620-4665$ (print)

ISSN : $2620-4673$ (online)

Website : http://jurnal.untan.ac.id/index.php/JPLP2KM

175). Teori ini menjelaskan bagaimana seseorang memperoleh sejumlah informasi dan dapat diingat dalam waktu yang cukup lama. Oleh karena itu perlu menerapkan suatu strategi belajar tertentu yang dapat memudahkan semua informasi diproses di dalam otak melalui beberapa indera.Kompenen pemrosesan dipilih menjadi tiga berdasarkan perbedaan fungsi, kapasitas, bentuk informasi, serta proses terjadinya "lupa". Ketiga komponen tersebut adalah Sensory receptor, Working memory dan Long term memory. Sedangkan proses kontrol diasumsikan sebgai strategi yang tersimpan didalam ingatan dan dapat dipergunakan setiap saat di perlukan.

\section{METODE}

Penyelesaian yang dilakukan untuk mengatasi masalah tersebut adalah dengan melakukan kegiatan dalam bentuk sosialisasi yang diikuti oleh anak-anak usia Sekolah Dasar khususnya Kelas 4 di SDN 04 Sungai Jaga A, Kec. Sungai Raya Kepulauan, Kabupaten Bengkayang sebanyak 31 siswa. Melalui kegiatan ini, diharapkan khalayak sasaran memiliki tambahan pengetahuan, kesadaran, dan kepedulian untuk terhadap kebakaan lahan pertanian di area gambut sehingga pada masa yang akan datang anak-anak tersebut tidak memiliki perilaku membakar khususnya pada lahan pertanian di area gambut. Metode yang digunakan dalam kegiatan ini adalah dengan cara ceramah dan dongeng di depan siswa siswi kelas 4 (empat).

Metode yang digunakan dalam kegiatan introduksi pencegahan kebakaran lahan pertanian di area gambut pada anak usia sekolah adalah dengan metode ceramah dan dongeng yang disertai dengan tanya jawab dengan khalayak sasaran. Media yang digunakan dalam kegiatan ini antara lain boneka kertas, spanduk, dan poster.

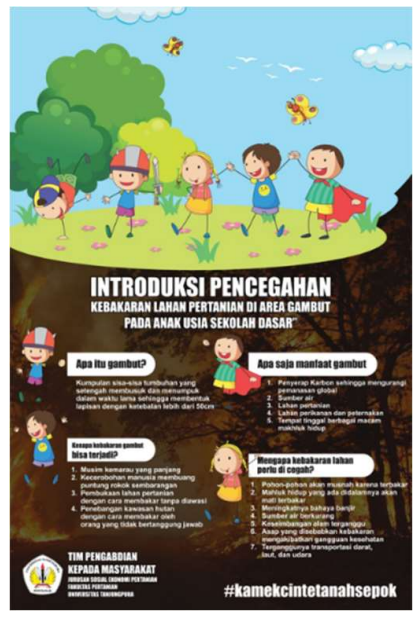

Gambar 1. Media Poster 
Tahapan dalam pelaksanaan kegiatan ini dibagi menjadi tiga, yaitu orientasi pendahuluan, pelaksanaan kegiatan, dan evaluasi kegiatan.

1. Orientasi pendahuluan, merupakan kegiatan pendahuluan untuk melihat kondisi tempat pelaksanaan kegiatan, khalayak sasaran serta perizinan kegiatan di tingkat desa. Penentuan khalayak sasaran merupakan hasil kesepakatan antara tim pelaksanan dan rekomendasi pihak desa serta persetujuan dari pihak Sekolah Dasar. Lokasi pelaksanaan kegiatan PKM adalah SDN 04 Sungai Jaga A, Kecamatan Sungai Raya Kepulauan, Kabupaten Bengkayang dengan khalayak sasaran kelas 4 SD .

2. Pelaksanaan kegiatan, merupakan kegiatan inti dimana tim pelaksana bertatap muka secara langsung dengan khalayak sasaran dalam menyampaikan materi dengan cara yang menyenangkan dengan menggunakan alat bantu seperti boneka kertas, poster, dan spanduk Adapun materi yang disampaikan meliputi :
a. Pengetahuan umum mengenai gambut;
b. Dampak negatif kebakaran lahan pertanian di area gambut;
C. Pencegahan kebakaran lahan pertanian di area gambut;
d. Kearifan lokal yang berhubungan dengan pertanian.

3. Evaluasi kegiatan, hal ini dilakukan untuk memperoleh gambaran sejauh mana penyampaian materi dapat diserap oleh khalayak sasaran. Indikator evaluasi keberhasilan keberhasilan pelaksanaan kegiatan introduksi pencegahan kebakaran lahan pertanian di area gambut pada anak sekolah dasar adalah

a. Tingkat antusiasme khalayak sasaran yang terlihat dari jumlah kehadiran dalam pelaksanaan kegiatan ini;

b. Adanya tanya jawab selama kegiatan berlangsung;

C. Khalayak sasran mau dan mampu untuk menyebarluaskan informasi atau pengetahuan yang diperoleh kepada orang lain sesuai dengan usia mereka.

\section{HASIL DAN PEMBAHASAN}

Kegiatan Pengabdian Kepada Masyarakat "Introduksi Pencegahan Kebakaran Lahan Pertanian di Area Gambut pada Anak Usia Sekolah Dasar" diikuti oleh 31 peserta yang merupakan anak-anak kelas 4 (empat) SDN 04 Sungai Raya, Kecamatan Sungai Raya 
ISSN : $2620-4665$ (print)

ISSN : 2620 - 4673 (online)

Website : http://jurnal.untan.ac.id/index.php/JPLP2KM

Kepulauan, Kabupaten Bengkayang. Kegiatan PKM berlangsung lancar, adapun rangkaian kegiatan yang dilaksanakan antara lain:

1. Ceramah mengenai pengetahuan umum tentang gambut dan lahan gambut khususnya.

Pemaparan materi ini bertujuan agar khalayak sasaran memperolah pengetahuan mengenai gambut yang berada di sekitar mereka dan manfaat adanya keberadaan gambut khususnya di Kalimantan Barat.

2. Pemberian materi mengenai kebakaran lahan pertanian di area gambut dengan cara mendongeng.

Dongeng dilakukan oleh tim pelaksana kegiatan PKM dengan dibantu oleh beberapa alat peraga dengan berbagai karakter seperti petani, polisi, kepala desa, dan beberapa hewan yang hidup di hutan dan lahan gambut. Pemilihan karakter disesuaikan dengan kondisi sosial ekonominya sehingga khalayak sasaran memperoleh gambaran yang utuh dan ikut membangun kesadaran serta kepekaan terhadap permasalahan yang ada di daerahnya. Selain itu, disampaikan pula materi mengenai dampak negatif kebakaran lahan pertanian di area gambut, pencegahan kebakaran lahan pertanian di area gambut, pengenalan kearifan lokal di bidang pertanian. Metode dongeng dipilih karena diharapkan informasi yang diberikan kepada khalayak sasaran lebih mudah dimengerti.

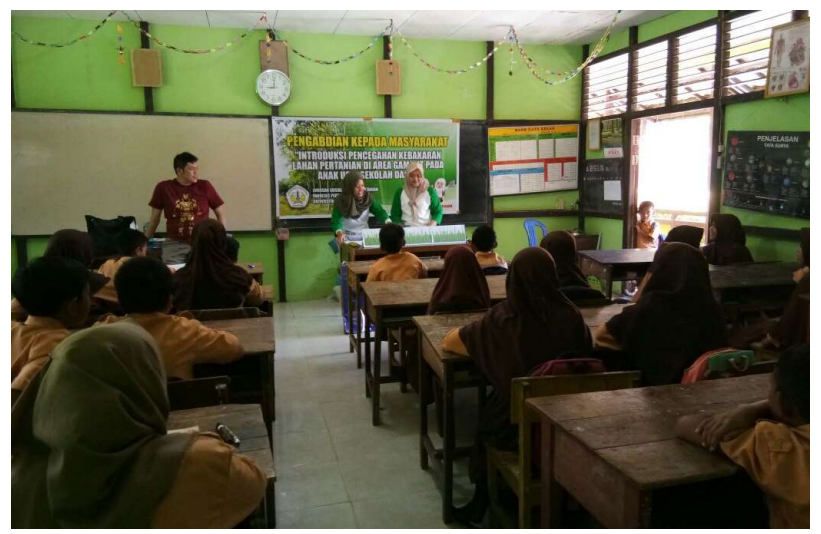

Gambar 2. Kegiatan Ceramah dan Mendongeng 
3. Bermain dan tanya jawab.

Selama kegiatan berlangsung juga terjadi proses tanya jawab dengan khalayak sasaran mengenai materi yang disampaikan. Selain itu, dilakukan juga permainan yang bersifat edukatif bagi khalayak sasaran.

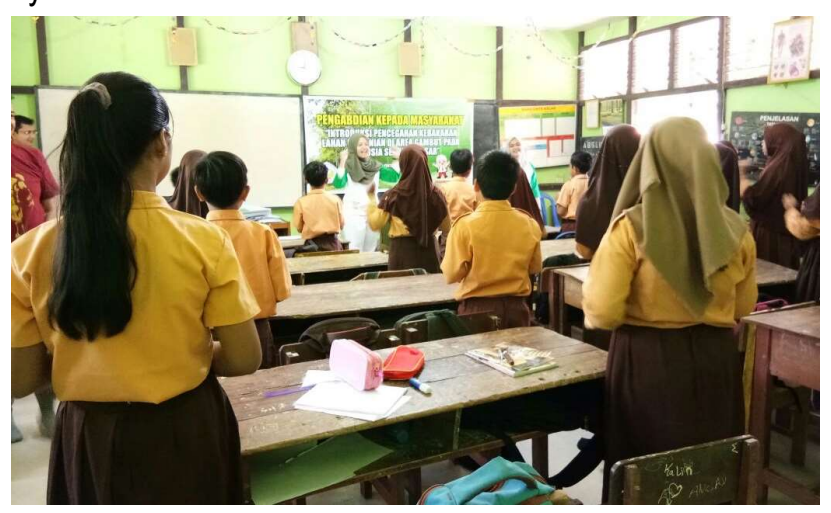

Gambar 3. Kegiatan Bermain dan Tanya Jawab

4. Pemberian poster dan alat peraga dongeng.

Poster diberikan kepada seluruh kelas 1 - 6 di SDN 04 Sungai Jaga A Kecamatan Sungai Raya Kabupaten Bengkayang. Pemberian poster ini bertujuan agar siswa-siswi maupun warga sekolah yang lainnya memperoleh informasi mengenai kebakaran lahan pertanian di area gambut. Pemberian poster ini diwakilkan kepada waki kelas 4 SD.

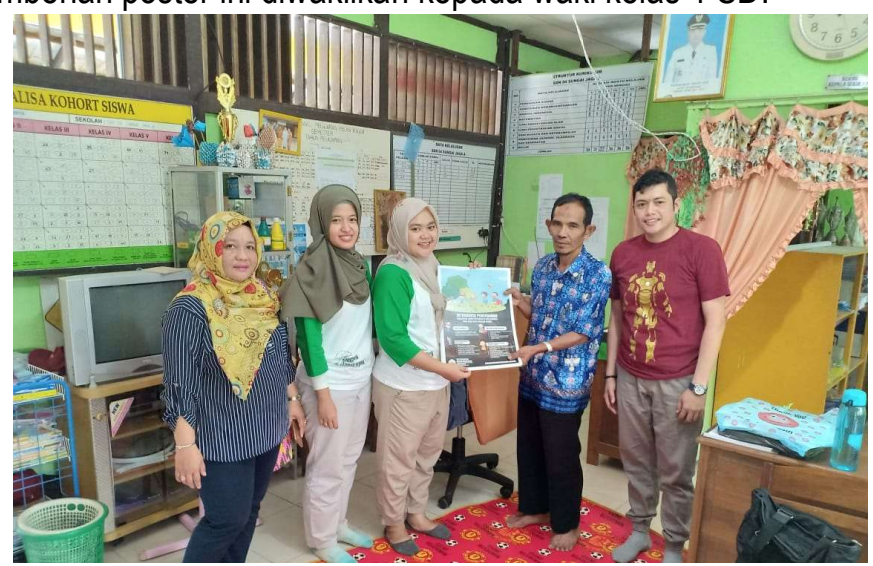

Gambar 4. Pemberian Poster dan alat Peraga dongeng

Beberapa khalayak sasaran berinisiatif untuk melakukan dongeng dengan tema yang sama pada saat perpisahan kelas $6 \mathrm{SD}$, sehingga alat peraga dongeng diberikan agar mereka mampu menyebarluaskan informasi yang mereka dapatkan kepada teman-teman sebayanya. 
ISSN : $2620-4665$ (print)

ISSN : 2620 - 4673 (online)

Website : http://jurnal.untan.ac.id/index.php/JPLP2KM

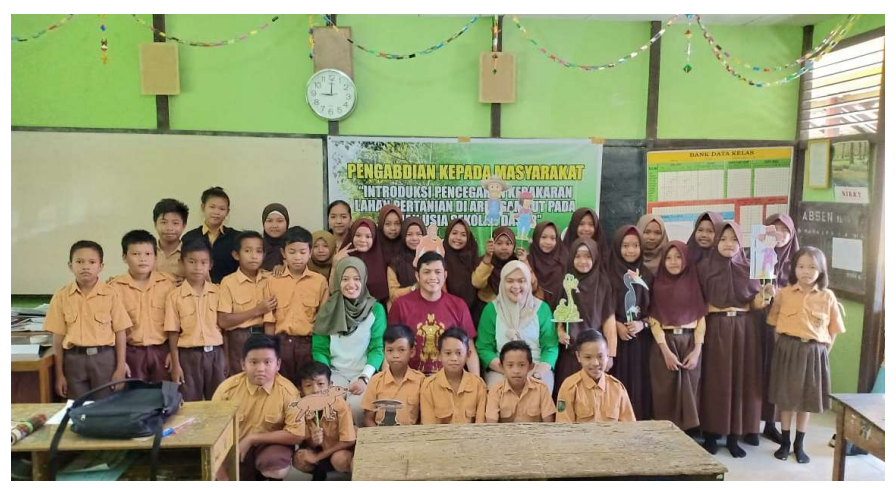

Gambar 5. Foto Tim Pelaksana dengan Khalayak Sasaran

Kegiatan "Introduksi Pencegahan Kebakaran Lahan Pertanian di Area Gambut pada Anak Usia Sekolah Dasar" dikatakan berhasil. Hal ini terlihat dari beberapa indikator, seperti tingginya antusias khalayak sasaran dalam mengikuti kegiatan, bahkan anak-anak kelas lainnya juga antusias menyaksikan kegiatan meskipun harus berdiri di luar kelas. Selain itu, khalayak sasaran juga banyak melakukan tanya jawab kepada tim pelaksana mengenai materi yang telah disampaikan. Khalayak sasaran juga tertarik dan berinisiatif untuk membawakan dongeng tentang kebakaran lahan pertanian di area gambut yang akan mereka tampilkan pada saat perpisahan kelas 6 (enam) mendatang. Pihak sekolah juga mengapresiasi dan antusias terhadap pelaksanaan kegiatan "Introduksi Pencegahan Kebakaran Lahan Pertanian di Area Gambut pada Anak Usia Sekolah Dasar". Hal ini terlihat dari sambutan pihak sekolah yang sangat baik dalam menyediakan tempat dan waktu serta koordinasi yang baik dengan tim pelaksana.

\section{SIMPULAN DAN REKOMENDASI}

\section{SIMPULAN}

Kegiatan PKM "Introduksi Pencegahan Kebakaran Lahan Pertanian di Area Gambut pada Anak Usia Sekolah Dasar" telah berhasil dilaksanakan di SDN 04 Sungai Jaga A, Kecamatan Sungai Raya Kepulauan, Kabupaten Bengkayang. Khalayak sasaran pada kegiatan ini adalah siswa SD kelas 4 (empat) yang diikuti sebanyak 31 siswa. Materi yang disampaikan kepada peserta meliputi mengenai dampak negatif kebakaran lahan pertanian di area gambut, pencegahan kebakaran lahan pertanian di area gambut, pengenalan kearifan lokal di bidang pertanian.

Melaui kegiatan PKM ini, tim pelaksana mengharapkan siswa-siswi peserta dapat bertambah pengetahuan, kesadaran, dan kepeduliannya terhadap kebakaran lahan pertanian di area gambut. Selain itu, peserta dapat meneruskan informasi yang diperoleh kepada teman- 
temannya dengan cara mereka sendiri sehingga anak-anak mengetahui akan pentingnya lahan gambut serta bahayanya kebakaran lahan pertanian di area gambut.

\section{REKOMENDASI}

Perlu adanya penyuluhan maupun sosialisasi lanjutan kepada pelajar dari tingkat Sekolah Dasar sampai Sekolah Menengah Atas sehingga para pelajar memiliki pengetahuan dan persepsi yang sama mengenai bahaya kebakaran lahan pertanian di area gambut dengan menggunakan metode yang sesuai dengan umurnya sebagai salah satu upaya tindakan pencegahan kebakaran lahan pertanian khususnya di Kalimantan Barat.

\section{ACKNOWLEDGEMENTS}

Terima kasih disampaikan kepada Universitas Tanjungpura memalaui Dana DIPA tahun anggaran 2018 yang telah membiayai pelaksanaan kegiaatan PKM ini, SDN 04 Sungai Jaga A Kecamatan Sungai Raya Kepulauan Kabupaten Bengkayang yang telah bersedia dan menyambut baik kegiatan ini, serta Kepala Desa serta jajaran Desa Sungai Jaga A yang telah memberikan pengarahan dan bantuan kepada tim pelaksana.

\section{DAFTAR PUSTAKA}

Anonymous. 2018. Kebakaran Hutan dan Lahan. https://belajarbencanalearndisaster.com/bencana-di-indonesia/kebakaran-hutan-danlahan/ diakses tanggal 3 Maret 2018.

Badan Nasional Penanggulangan Bencana. 2017. Definisi dan Jenis Bencana. https://www.bnpb.go.id/home/definisi diakses tanggal 3 Maret 2018.

Budiansyah. 2012. Teori Perkembangan Anak Sekolah Dasar. 2012. http://budiansyahunj.blogspot.co.id/2012/12/teori-perkembangan-anak-sekolah-dasarsd.html diakses tanggal 3 Maret 2018.

Tim Survey Sosek Untan. 2015. Laporan Final Survey Sosial Ekonomi Pertanian Tahun Kelima. Universitas Tanjungpura. Pontianak. 